\title{
Pemberdayaan Masyarakat melalui Pelatihan Mitigasi dan Kesiapsiagaan Bencana di Nagari Pakan Sinayan
}

\author{
Rahmi Muthia, Fitri Mailani, dan Emil Huriani \\ Fakultas Keperawatan, Universitas Andalas, Kampus Limau Manis, Padang, 25163. Indonesia \\ E-mail: rahmimuthia@nrs.unand.ac.id
}

Keywords:

disaster,

empowerment, mitigation, preparedness

\begin{abstract}
Disasters can come suddenly at anytime and anywhere. Disasters can result in many casualties, injuries, and material loss. Therefore, the community must understand the threat of a disaster, have knowledge about disaster preparedness. The purpose of this activity is to provide education and training on disaster management that may occur in the Pakan Sanayan village, Banuhampu District. The activity was held on August 8, 2020 in Nagari Pakan Sinayan, Banuhampu District, Agam Regency, and was attended by 47 community members. The activity begins with conducting a pretest to the training participants, providing material on potential disaster analysis followed by a discussion on disaster risk analysis that may occur in the Pakan Sinayan area. The material was continued with disaster mitigation and preparedness, especially disasters that could potentially occur in the area, namely landslides, earthquakes, fires and volcanic eruptions. The results of the evaluation showed an increase in public understanding and knowledge of disasters. It is recommended that this activity be carried out continuously to encourage community empowerment in improving disaster preparedness.
\end{abstract}

\begin{abstract}
ABSTRAK
Bencana bisa datang tiba-tiba kapan saja dan dimana saja. Bencana dapat mengakibatkan banyak korban jiwa, luka-luka, maupun kerugian materi. Oleh karena itu masyarakat harus memahami ancaman bencana dan memiliki pengetahuan tentang kesiapsiagaan mengatasi bencana. Tujuan kegiatan ini adalah untuk memberikan pendidikan dan pelatihan penanggulangan bencana yang mungkin terjadi di nagari Pakan Sanayan kecamatan Banuhampu. Kegiatan dilaksanakan pada tanggal 8 Agustus 2020 di Nagari Pakan Sinayan Kecamatan Banuhampu Kabupaten Agam, dan dihadiri oleh 47 orang warga masyarakat. Kegiatan diawali dengan melakukan pretest kepada peserta pelatihan, pemberian materi analisa potensi bencana dilanjutkan dengan diskusi tentang analisa resiko bencana yang mungkin terjadi di nagari Pakan Sinayan. Materi dilanjutkan dengan mitigasi dan kesiapsiagaan bencana, terutama bencana yang berpotensi terjadi di daerah tersebut yaitu longsor, gempa bumi, kebakaran dan erupsi gunung api. Hasil evaluasi menunjukkan peningkatan pemahaman dan pengetahuan masyarakat mengenai bencana. Disarankan kegiatan ini dilakukan berkesinambungan untuk mendorong pemberdayaan masyarakat dalam meningkatkan kesiapsiagaan menghadapi bencana.
\end{abstract}




\section{PENDAHULUAN}

Indonesia merupakan salah satu negara yang rawan terkena bencana. Pada Tahun 2018 kejadian bencana di Indonesia berjumlah 2.572 bencana, dengan jumlah korban meninggal dunia 4.814 jiwa. Sumatera Barat merupakan salah satu provinsi dengan kejadian bencana tertinggi di Indonesia. Sepanjang tahun 2019 Sumatera Barat mengalami 746 total kejadian bencana dengan total kerugian mencapai 166 Triliun (Pusdalops PBBPBD Provinsi Sumatera Barat, 2019). Hal ini membuktikan, meski sering dilanda bencana, kemampuan dalam menanggulangi bencana di tengah mayarakat belum banyak perubahan. Kejadian bencana yang terjadi di Indonesia masih mengakibatkan banyak korban jiwa, kerugian harta benda dan kerusakan lingkungan.

Kabupaten Agam adalah satu satu kabupaten/kota dengan jenis penyebaran resiko bencana terlengkap di Sumatera Barat. Sehingga manajemen bencana berupa suatu proses terencana yang dilakukan untuk mengelola bencana dengan baik dan aman harus terus dijalankan di daerah ini. Penanggulangan bencana terdiri atas 3 (tiga) tahapan: (1) pra bencana, (2) saat bencana, (3) pasca bencana. Pada masa pra bencana dimana tidak terjadi bencana namun terdapat potensi bencana yang dapat dilakukan adalah upaya mitigasi dan kesiapsiagaan bencana (Ramli, 2010).

Penanggulangan bencana harus dilakukan dengan cara yang lebih bijak, tidak hanya dengan pendekatan hard power tapi soft power. Pendekatan hard power adalah upaya menghadapi bencana melalui pembangunan fisik seperti membangun sarana komunikasi, tanggul, mendirikan dinding beton, mengeruk sungai dan sebagainya. Sedangkan pendekatan soft power merupakan usaha membangun kesiagaan masyarakat melalui sosialisasi dan pemberian informasi, baik edukasi maupun pelatihan (Rudianto, 2012).

Kegiatan promosi dan menyebarluaskan informasi ini dapat dilakukan salah satunya melalui pendidikan dan pelatihan. Pendidikan adalah segala upaya yang direncanakan untuk mempengaruhi orang lain baik individu, kelompok atau masyarakat sehingga mereka melakukan apa yang diharapkan oleh pelaku pendidikan (Notoatmodjo, 2005). Sedangkan pelatihan adalah proses pendidikan dalam usaha meningkatkan kualitas dan kompetensi peserta pelatihan untuk masa sekarang dan akan datang, serta dilaksanakan dalam jangka pendek dengan cara praktis dan sistematis (Daud dkk., 2014).

Pengabdian masyarakat sebelumnya yang dilakukan oleh Afrianti dkk. (2019) menyatakan bahwa terdapat peningkatan pengetahuan masyarakat muda sekolah setelah diberikan penyuluhan tentang mitigasi dan tanggap bencana. Selain itu dalam pengabdian masyarakat berupa pendidikan kesiapsiagaan bencana pada anggota keluarga yang dilakukan oleh Mahathir (2019) menunjukkan peningkatan pada pengetahuan dan kesadaran dasar kesiapsiagaan bencana yang menandai upaya penting untuk meningkatkan ketahanan keluarga melalui kesiapsiagaan bencana.

Berdasarkan latar belakang di atas tim penulis tergerak melakukan kegiatan pemberdayaan masyarakat melalui pelatihan mitigasi dan kesiapsiagaan bencana di Nagari Pakan Sinayan Kecamatan Banuhampu Kabupaten Agam, sebagai upaya membangun kesadaran kolektif dalam masyarakat untuk mengantisipasi terjadinya bencana, memahami ancaman bencana dan memiliki pengetahuan tentang penanggulangan bencana, sehingga mampu melakukan mitigasi dan kesiapsiagaan jika sewaktu-waktu bencana terjadi.

\section{METODE}

Kegiatan pemberdayaan masyarakat melalui pelatihan mitigasi dan kesiapsiagaan bencana di Nagari Pakan Sinayan Kecamatan Banuhampu Kabupaten dilaksanakan pada tanggal 8 
Agustus 2020 di Nagari Pakan Sinayan Kecamatan Banuhampu Kabupaten Agam, dan dihadiri oleh 47 orang warga masyarakat. Menurut Haryono (2012) metode yang tepat dalam penanganan bencana adalah Kesiapsiagaan Bencana Berbasis Masyarakat. Metode ini menitikberatkan pada pemberdayaan masyarakat yaitu usaha untuk mengubah masyarakat dengan melibatkan masyarakat itu sendiri dalam aktivitas lobi, dukungan, kritik yang membangun kesadaran, pengkondisian, dan pengembangan edukasi sosial (Whitehead, 2004). Sehingga terjadi perubahan paradigma dalam masyarakat Indonesia untuk bergerak secara mandiri dan gotong royong (mempersiapkan diri) dalam menghadapi bencana (Herianto; Nulhaqim; dan Rachim, 2015).

Pemberdayaan masyarakat dilakukan melalui pendidikan, pelatihan dan pemberian buku "Tangguh Menghadapi Bencana" yang sudah disiapkan oleh tim. Adapun proses pelaksanaan kegiatan dilakukan dengan tahapan sebagai berikut:

A. Sebelum pelaksanaan kegiatan

1. Menyiapkan media yang akan memfasilitasi pemberdayaan masyarakat meliputi booklet tentang ancaman bencana di Indonesia dan upaya mitigasinya.

2. Menjalin kerjasama dengan Pemerintah Nagari dan masyarakat dalam pelaksanaan kegiatan Pemberdayaan Masyarakat Melalui Pelatihan Mitigasi Bencana di Nagari Pakan Sinayan Kecamatan Banuhampu Kabupaten Agam dan menentukan waktu kegiatan dimana undangan kegiatan akan diberikan.

B. Saat pelaksanaan kegiatan

1. Mengisi angket resiko Bencana

2. Melakukan pre test

3. Pembukaan

4. Melakukan edukasi analisa resiko bencana dan melakukan diskusi resiko bencana Nagari Pakan Sinayan

5. Melakukan edukasi dan pelatihan mitigasi dan kesiapsiagaan bencana kebakaran

6. Melakukan edukasi dan pelatihan mitigasi dan kesiapsiagaan bencana erupsi gunung api

7. Melakukan edukasi dan pelatihan mitigasi dan kesiapsiagaan bencana gempa bumi

8. Melakukan edukasi dan pelatihan mitigasi dan kesiapsiagaan bencana longsor

9. Melakukan evaluasi kegiatan edukasi yang dilakukan (post test)

10. Membagikan buku "Tangguh Menghadapi Bencana" sebagai sarana pemberdayaan masyarakat.

\section{HASIL DAN PEMBAHASAN}

Pendidikan dan pelatihan penanggulangan bencana ini dilaksanakan pada tanggal 8 Agustus 2020. Kegiatan ini sangat didukung dan diapresiasi oleh masyarakat dan pemerintah nagari Pakan Sinayan. Hanya saja karena penundaan jadwal kegiatan ke hari Sabtu akibat kegiatan lain dari para pemateri yang tidak bisa ditinggalkan, serta pertimbangan kondisi Covid - 19 yang menuntut phisical distancing kegiatan yang semula akan dilaksanakan di kantor wali nagari dipindahkan ke salah satu Mushala Nagari Pakan Sinayan yaitu Mushala Nurul Hidayah.

Materi pendidikan dan pelatihan mitigasi dan kesiapsiagaan bencana disampaikan oleh tim dosen dari Fakultas Keperawatan yang terdiri dari Ns. Rahmi Muthia, M.Kep, Ns. Fitri Mailani, M.Kep, dan Emil Huriani, S.Kp, MN, serta dibantu oleh dua orang mahasiswa profesi Ners bernama Yeni Fajria, S.Kep dan Syifa Arini, S.Kep. Kegiatan ini dihadiri oleh 47 orang warga masyarakat dan dilakukan dengan tetap memperhatikan protokol Covid-19. Adapun karakteristik demografi peserta pelatihan terdapat pada Tabel 1. 
Tabel 1. Karakteristik Masyarakat yang Mengikuti Program Edukasi

\begin{tabular}{|c|c|c|}
\hline Karakteristik & Frekuensi & Persentase (\%) \\
\hline \multicolumn{3}{|l|}{ Jenis kelamin } \\
\hline Laki-laki & 3 & $6,38 \%$ \\
\hline Perempuan & 44 & $93,62 \%$ \\
\hline \multicolumn{3}{|l|}{ Pendidikan Terakhir } \\
\hline - $\quad$ SARJANA & 6 & $12,77 \%$ \\
\hline - SMA & 18 & $38,30 \%$ \\
\hline - SMP & 11 & $23,40 \%$ \\
\hline$-\quad \mathrm{SD}$ & 11 & $23,40 \%$ \\
\hline - $\quad$ Tidak lulus & 1 & $2,13 \%$ \\
\hline \multicolumn{3}{|l|}{ Agama } \\
\hline - Islam & 47 & $100 \%$ \\
\hline \multicolumn{3}{|l|}{ Pekerjaan } \\
\hline - PNS & 1 & $2,13 \%$ \\
\hline - Guru & 2 & $4,26 \%$ \\
\hline - Tani & 2 & $4,26 \%$ \\
\hline$-\quad$ IRT & 28 & $59,57 \%$ \\
\hline - Swasta & 7 & $14,89 \%$ \\
\hline - Mahasiswa & 4 & $8,51 \%$ \\
\hline - Exmahasiswa & 1 & $2,13 \%$ \\
\hline - Pelajar & 2 & $4,26 \%$ \\
\hline \multicolumn{3}{|l|}{ USIA } \\
\hline - $\quad$ Remaja (18-25) & 9 & $19,15 \%$ \\
\hline - Dewasa awal (26-35) & 14 & $29,79 \%$ \\
\hline - Dewasa akhir (36-45) & 10 & $21,28 \%$ \\
\hline - Lansia awal (46-55) & 10 & $21,28 \%$ \\
\hline - $\quad$ Lansia akhir (lebih dari 56) & 4 & $8,51 \%$ \\
\hline
\end{tabular}

Dari tabel di atas dapat dilihat bahwa sebagian besar masyarakat yang mengikuti pelatihan adalah perempuan $(93,62 \%)$, mayoritas pendidikan terakhir yaitu SMA $(38,30 \%)$, dengan usia didominasi usia dewasa awal (29,79\%), seluruhnya beragama Islam (100\%) dan pekerjaan dominan adalah ibu rumah tangga atau IRT (59,57\%).

Kegiatan diawali dengan pengisian angket singkat oleh peserta untuk menilai potensi bencana pada daerah tersebut, selanjutnya dilakukan penyampaian materi pengantar tentang analisa resiko bencana dan dilanjutkan dengan diskusi analisa resiko bencana di daerah setempat. Pada tahap ini peserta berdiskusi dengan antusias karena sebagian besar pernah menjadi korban bencana yang memiliki pengalaman dalam kerugian harta benda dan luka ringan di keluarga serta pengalaman mengungsi ke tenda saat kejadian bencana sebelumnya. Dari hasil diskusi verbal dan pembacaan isian angket masyarakat, ditemukan bahwa bencana yang berpotensi besar terjadi di daerah tersebut yaitu gempa bumi, longsor, kebakaran dan erupsi gunung api.

Setelah menganalisis resiko bencana yang mungkin terjadi di daerah Pakan Sinayan dilanjutkan dengan pendidikan dan pelatihan materi mitigasi dan kesiapsiagaan bencana, terutama yang paling berpotensi terjadi di daerah tersebut yaitu gempa bumi, longsor, kebakaran dan erupsi gunung api. Pemateri menjelaskan berbagai cara pencegahan, memitigasi, melakukan kesiapsiagaan, dan penyelamatan diri saat terjadi bencana-bencana tersebut. Media yang digunakan adalah power point dan video. 
Evaluasi kegiatan dilakukan dengan melakukan perbandingan pengetahuan masyarakat akan bencana dengan membandingkan tingkat pengetahuan saat pretest dan postest. Pretest terdiri dari kuesioner yang lebih lengkap untuk mengetahui kesiapsiagaan masyarakat akan bencana. Indikator yang digunakan untuk menilai kesiapsiagaan masyarakat diturunkan dari lima parameter menurut LIPI-UNESCO/ISDR (2006) dengan sedikit modifikasi, yang mengukur mengenai pengetahuan dan sikap terhadap resiko bencana; kebijakan dan panduan; rencana untuk keadaan darurat bencana; sistem peringatan bencana; dan kemampuan untuk memobilisasi sumber daya. Sedangkan soal postest adalah soal pretest yang menilai pengetahuan saja. Penilaian ini berfokus pada keluarga sebagai objek kajian.

Kesiapsiagaan masyarakt nagari Pakan Sinayan dalam menghadapi bencana saat ini tergambar pada hasil pretest, sebagaimana yang terangkum pada Tabel 2 .

Tabel 2. Kesiapsiagaan Masyarakat dalam Mengahadapi Bencana

\begin{tabular}{ll}
\hline Materi & Rata-rata (min- max) \\
\hline Pengetahuan tentang bencana & $69.67 \%(29.36 \%-88,3 \%)$ \\
Rencana kesiapsiagaan keluarga dari bencana & $55.53 \%(25.53 \%-84.57 \%)$ \\
Sistem peringatan bencana & $56.74(37.23 \%-84.57 \%)$ \\
Mobilisasi sumber daya & $51.64 \%(35.32 \%-63.83 \%)$ \\
\hline
\end{tabular}

Dari Tabel 2 diketahui kesiapsiagaan masyarakat nagari Pakan Sinayan dalam menghadapi bencana sebelum dilakukan pelatihan. Berdasarkan pengetahuan keluarga tentang bencana masyarakat mendapatkan variasi skor kurang (29.36\%) hingga sangat baik $(88.3 \%)$, dengan rata-rata berpengetahuan baik (69.67\%). Sedangkan berdasarkan indikator rencana kesiapsiagaan keluarga dalam menghadapi bencana masyarakat mendapatkan variasi skor kurang (25.53\%) hingga sangat baik (84.57\%), dengan rencana kesiapan keluarga cukup (55.53\%). Untuk aksen sistem peringatan bencana masyarakat mendapatkan variasi skor kurang (37.23\%) hingga sangat baik (84.57\%) dengan rata-rata akses pada sistem peringatan bencana cukup $(56.74 \%)$. Untuk usaha memobilisasi sumber daya keluarga mendapatkan variasi skor kurang (35.32\%) hingga baik (63.83\%) dengan rata-rata memobilisasi sumber daya cukup (51.64\%).

Berdasarkan hasil prestest tersebut diketahui bahwa kesiapsiagaan masyarakat dalam menghadapi bencana sangat bervariasi dari kurang hingga sangat baik dengan rata-rata cukup. Tidak jauh berbeda dengan penelitian sebelumnya menurut Damayanti (2017) yang meneliti kepala keluarga tentang hubungan pengetahuan tentang manajemen bencana dalam menghadapi bencana gunung meletus di Desa Puncu Kecamatan Puncu Kediri, diperoleh data pengetahuan kepala keluarga memiliki pengetahuan yang berbeda-beda. Begitu juga dalam penelitian Susanto (2016) yang mengukur indeks kesiapsiagaan warga di 19 lokasi titik penelitian rawan bencana longsor di Semarang menemukan secara umum kesiapsiagaan masyarakat Semarang masuk dalam kategori "Hampir Siap" dengan nilai indeks 55,74 yang berada di posisi tengah pada tingkatan kesiapan mengahadapi bencana.

Kesiapsiagaan dalam menghadapi bencana merupakan hal yang penting karena mampu meminimalisir dampak bencana. Perilaku kesiapsiagaan ditentukan oleh pengetahuan, sikap, kepercayaan, tradisi, dan banyak lagi lainnya. Effendy (2003) menjelaskan bahwa perubahan sikap bergantung pada proses yang terjadi didalam diri individu tersebut. Pada prestest ditemukan walaupun rata-rata pengetahuan tentang bencana pada masyarakat baik namun rencana kesiapsiagan keluarga, akses sistem peringatan bencana, dan memobilisasi sumber daya masyarakat rata-rata memiliki skor cukup. 
Pengetahuan yang cukup baik dibandingkan 4 elemen kesiapsiagaan lain dapat dijelaskan dan dihubungkan dengan analisa resiko bencana dimana daerah ini pernah dilanda beberapa bencana sebelumnya, sehingga masyarakat memiliki pengalaman dan pengetahuan yang cukup memadai terkait bencana tertentu. Ini didukung oleh penelitian Damayanti (2017) dimana pengetahuan akan sesuai dengan pengalaman dan informasi yang diperoleh sebelumnya.

Pada elemen rencana kesiapsiagan keluarga, sistem peringatan bencana, dan memobilisasi sumber daya rata-rata nilai peserta adalah cukup siap. Ini bisa berhubungan dengan kurangnya pendidikan kesiapsiagaan bencana yang dijalani masyarakat Pakan Sinayan sebelumnya. Menurut pengabdian masyarakat yang hamper serupa dilakukan Mahathir (2019) pendidikan kesiapsiagaan bencana menandai upaya penting untuk meningkatkan ketahanan keluarga akan bencana.

Tindakan kesiapsiagaan dengan membuat rencana pengungsian/evakuasi keluarga, pelatihan evakuasi, menyiapkan perlengkapan untuk kondisi emergensi (emergency bag), menyimpan/menghafal alamat-alamat/nomor telpon yang penting. Inilah yang belum cukup disiapkan oleh masyarakat pada rencana kesiapsiagaan keluarga. Untuk mencapai ini kesadaran dan pengetahuan masyarakat harus ditingkatkan. Materi analisa resiko bencana merupakan langkah awal dalam menumbuhkan kesadaran pada masyarakat akan resiko bencana yang ada di sekitar mereka. Menurut Jati (2013) persepsi publik tentang bencana memegang peranan penting dalam penanganan bencana. Perubahan perilaku ditentukan oleh konsep risiko, Sedangkan penentu respon individu untuk mengubah perilaku adalah tingkat beratnya risiko (Emilia, 2008).

Kegiatan pemberdayaan masyarakat ini dimulai dengan pemberian materi analisa resiko bencana wilayah, dimana setelah diberikan pemaparan materi mayarakat melakukan diskusi dan menganalisa resiko bencana yang mungkin terjadi di daerah Pakan Sinayan. Menurut Nursalam dan Efendi (2008) dalam proses pembelajaran orang dewasa memerlukan pendekatan dimana orang yang menyampaikan materi tidak boleh menempatkan dirinya sebagai orang yang paling tahu tetapi memposisikan diri sebagai fasilitator. Dalam kegiatan ini peserta menilai potensi bencana pada daerah mereka sendiri.

Setelah diskusi analisa resiko bencana, masyarakat diberikan pemaparan dan penjelasan video tentang mitigasi dan kesiapsiagaan bencana. Menurut penelitian Daud (2014) pelatihan berpengaruh terhadap sikap. Selain itu, sikap yang didasarkan pada pengetahuan akan dapat dimanfaatkan dalam jangka panjang. Sehingga pelatihan kesiapsiagaan menghadapi bencana sangat diperlukan. Kesiapsiagaan dalam menghadapi bencana diharapkan dapan mengurangi dampak bencana. Berdasarkan hasil diskusi bencana yang berpotensi terjadi di daerah tersebut adalah longsor, gempa bumi, kebakaran dan erupsi gunung api. Sehingga kegiatan dilanjutkan dengan pelatihan mitigasi dan kesiapsiagaan terhadap bencana longsor, gempa bumi, kebakaran dan erupsi gunung api.

Peningkatan pengetahuan dinilai secara kuantitatif dengan membandingkan skor pengetahuan tentang bencana pada awal (pretest) dan pengetahuan bencana pasca kegiatan pelatihan (posttest), sebagaimana yang terangkum pada Tabel 3. Pada tabel terlihat bahwa terjadi peningkatan skor pengetahuan pada semua item pengetahuan yang diuji. Hasil ini hampir sama dengan pengabdian masyarakat sebelumnya yang dilakukan oleh Afrianti, dkk (2019) bahwa terdapat peningkatan pengetahuan masyarakat muda sekolah setelah diberikan penyuluhan tentang mitigasi dan tanggap bencana. Menurut Kurniawati (2016) pendidikan merupakan media terbaik untuk meningkatkan pengetahuan dan pemahaman tentang bencana suatu komunitas. 
Tabel 3. Gambaran Peningkatan Pengetahuan Sebelum dan Sesudah Kegiatan

\begin{tabular}{ll|l}
\hline Komponen Evaluasi & $\begin{array}{l}\text { Pre test } \\
\mathbf{( \% )}\end{array}$ & $\begin{array}{l}\text { Post test } \\
\text { (\%) }\end{array}$ \\
\hline Apa yang dimaksud dengan bencana alam? & $69,68 \%$ & $91,49 \%$ \\
\hline Apa saja kejadian alam yang dapat menimbulkan bencana? & $87,94 \%$ & $100 \%$ \\
\hline Apa saja penyebab terjadinya gempa bumi? & $65,96 \%$ & $95,74 \%$ \\
\hline Apa saja bencana alam yang dapat diakibatkan oleh gempa? & $65,96 \%$ & $97,87 \%$ \\
\hline Apakah gempa bumi dapat diperkirakan terjadinya? & $78,72 \%$ & $100 \%$ \\
\hline Apa ciri-ciri gempa kuat? & $81,38 \%$ & $100 \%$ \\
\hline Apa yang dapat dilakukan bila terjadi gempa? & $70,21 \%$ & $87,23 \%$ \\
\hline Kejadian yang dapat menyebabkan tsunami adalah? & $76 \%$ & $100 \%$ \\
\hline Tanda-tanda gejala tsunami sebagai berikut & $34,89 \%$ & $68,09 \%$ \\
\hline Informasi bencana bisa di dapatkan melalui & $77,93 \%$ & $100 \%$ \\
\hline Penyebab utama banjir adalah & $88,3 \%$ & $100 \%$ \\
\hline Tindakan manusia yang dapat menyebabkan terjadinya banjir & $68,62 \%$ & $100 \%$ \\
\hline Yang merupakan aktifitas gunung berapi adalah? & $82,98 \%$ & $100 \%$ \\
\hline Yang dilakukan saat terjadi erupsi gunung api & $86,81 \%$ & $100 \%$ \\
\hline Tanda tanah akan mengalami longsor adalah & $74,89 \%$ & $93,62 \%$ \\
\hline Yang dapat digunakan untuk memadamkan api adalah & $69,68 \%$ & $100 \%$ \\
\hline $\begin{array}{l}\text { Yang merupakan kegiatan pada tahap pra bencana dalam siklus } \\
\text { manajemen bencana adalah }\end{array}$ & $45,96 \%$ & $76,60 \%$ \\
\hline $\begin{array}{l}\text { Upaya untuk mengurangi resiko bencana seperti pembuatan } \\
\text { tanggul sungai dan membuat sistem peringatan bencana } \\
\text { merupakan tindakan... }\end{array}$ & $57,87 \%$ & $61,70 \%$ \\
\hline $\begin{array}{l}\text { Mengetahui tindakan-tindakan cepat dan tepat dalam menghadapi } \\
\text { bencana dalam rangka meminimalisir kerugian akibat bencana } \\
\text { merupakan kegiatan. }\end{array}$ & $29,36 \%$ & $82,98 \%$ \\
\hline Tas siaga bencana berisikan... & $80,85 \%$ & $100 \%$ \\
\hline
\end{tabular}

Pada kegiatan ini tidak dilakukan evaluasi akhir terhadap elemen rencana kesiapsiagaan keluarga, sistem peringatan bencana, dan memobilisasi sumber. Karena penulis menilai elemen ini tidak cocok dinilai sesaat setelah pendidikan dan pelatihan diberikan, karena akan membutuhkan waktu yang lebih banyak untuk menerapkan rencana kesiapsiagaan keluarga, sistem peringatan bencana, dan memobilisasi sumber dibandingkan perubahan pengetahuan anggota keluarga setelah dilakukan pendidikan dan pelatihan. Namun diharapkan pendidikan yang dilakukan mempunyai peran yang dapat memengaruhi terhadap perilaku kesiapsiagaan bencana. Sesuai dengan hasil pengabdian masyarakat yang dilakukan Mahathir (2019) bahwa peningkatan pada pengetahuan dan kesadaran dasar kesiapsiagaan bencana, akan menandai upaya penting untuk meningkatkan ketahanan keluarga melalui kesiapsiagaan bencana.

Untuk membantu keberlangsungan peningkatan ketahanan keluarga melalui kesiapsiagaan bencana, tim memfasilitas peserta pelatihan ini untuk melakukan pemberdayaan mitigasi dan kesiapsiagaan bencana pada anggota keluarga dan masyarakat mereka, dengan memberikan buku yang dapat dibaca dan menjelaskan kembali isi kegiatan pelatihan pada keluarga di rumah dan masyarakat. Sehingga keluarga sebagai unit terkecil dari masyarakat memiliki ilmu dalam menghadapi bencana, terlatih dan memiliki budaya sadar bencana, sehingga mampu mempersiapkan diri dengan penanggulangan bencana, untuk melakukan pencegahan dan meminimalkan resiko, menyelamatkan diri dan meminimalisasi korban ketika terjadi bencana. 


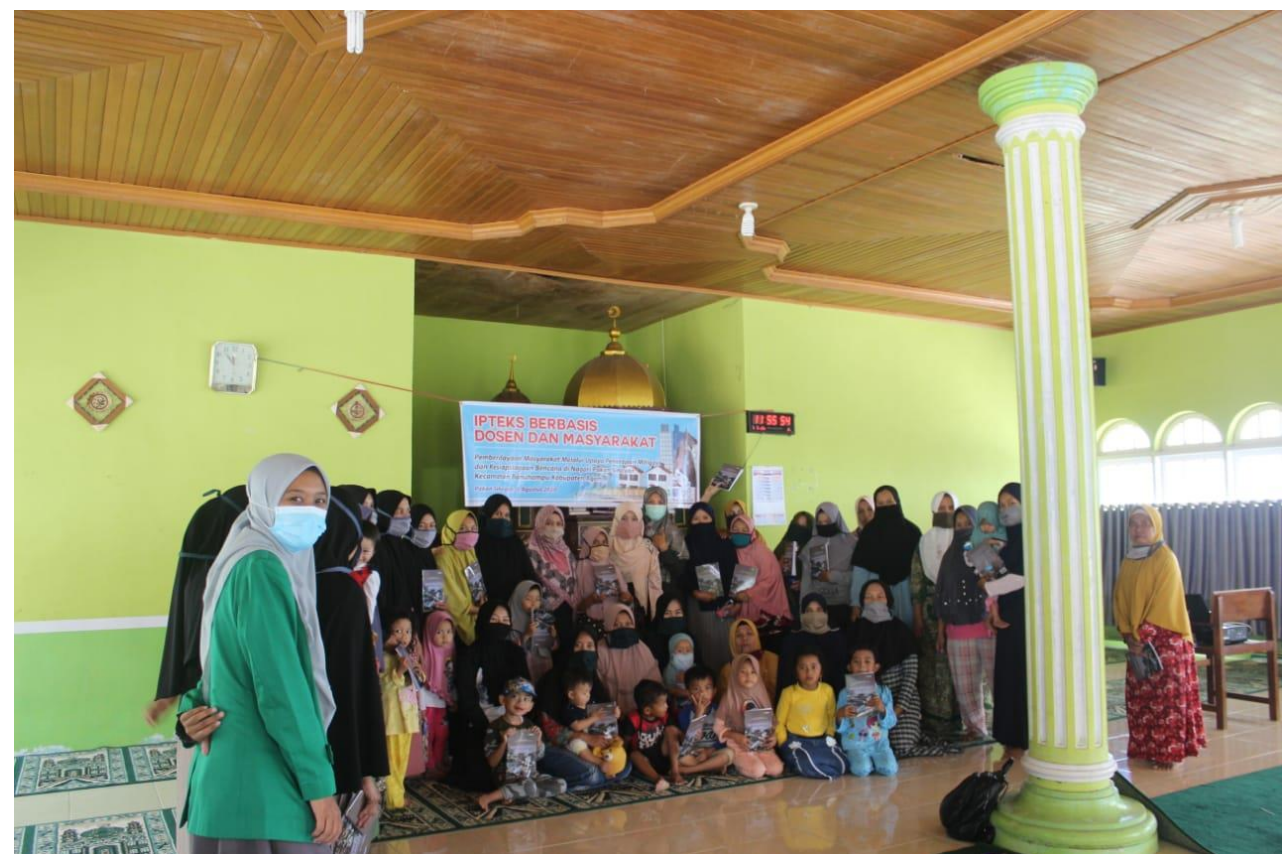

Gambar 1. Foto dengan masyarakat yang mengikuti kegiatan pendidikan dan pelatihan

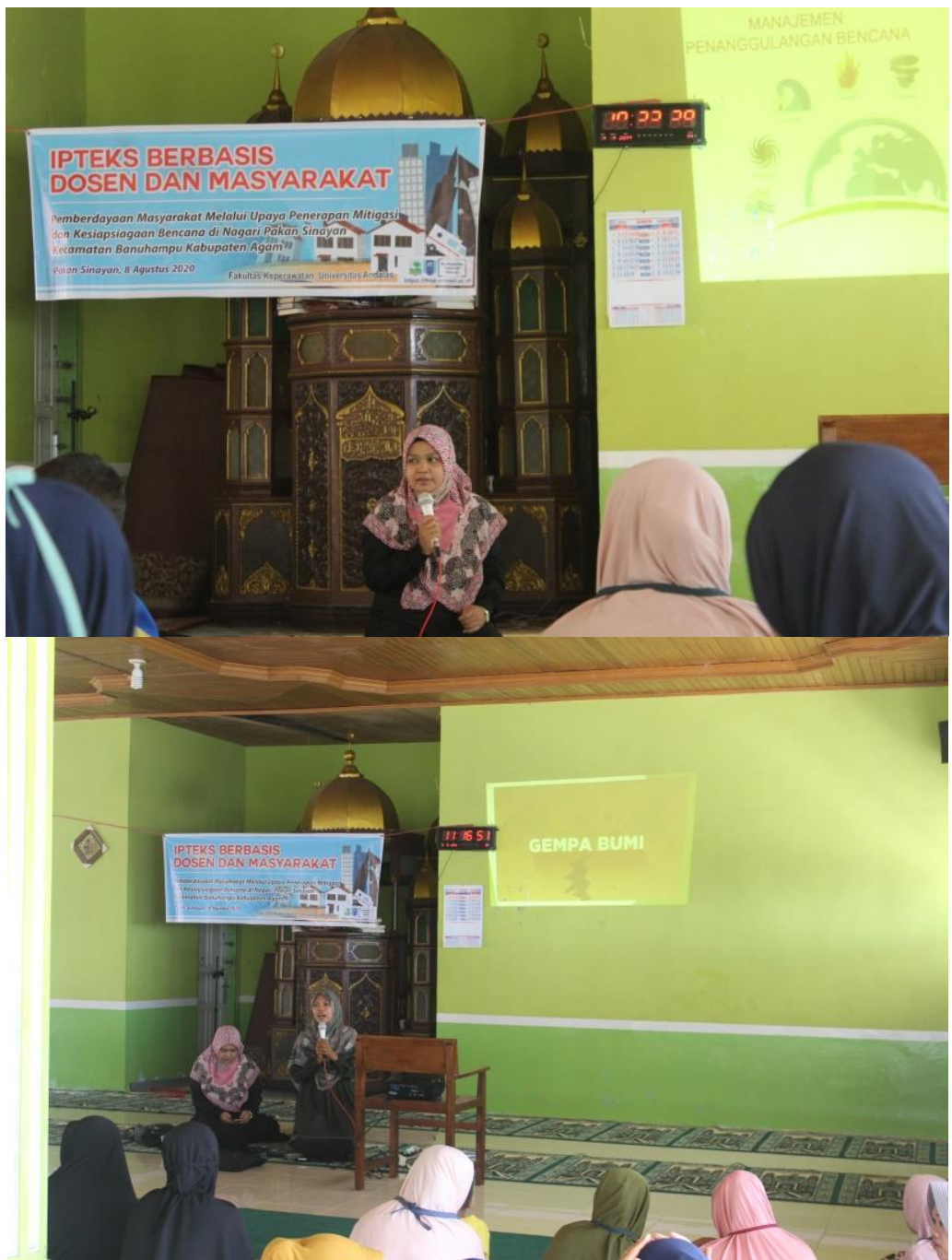

Gambar 2. Penyampaian Materi 


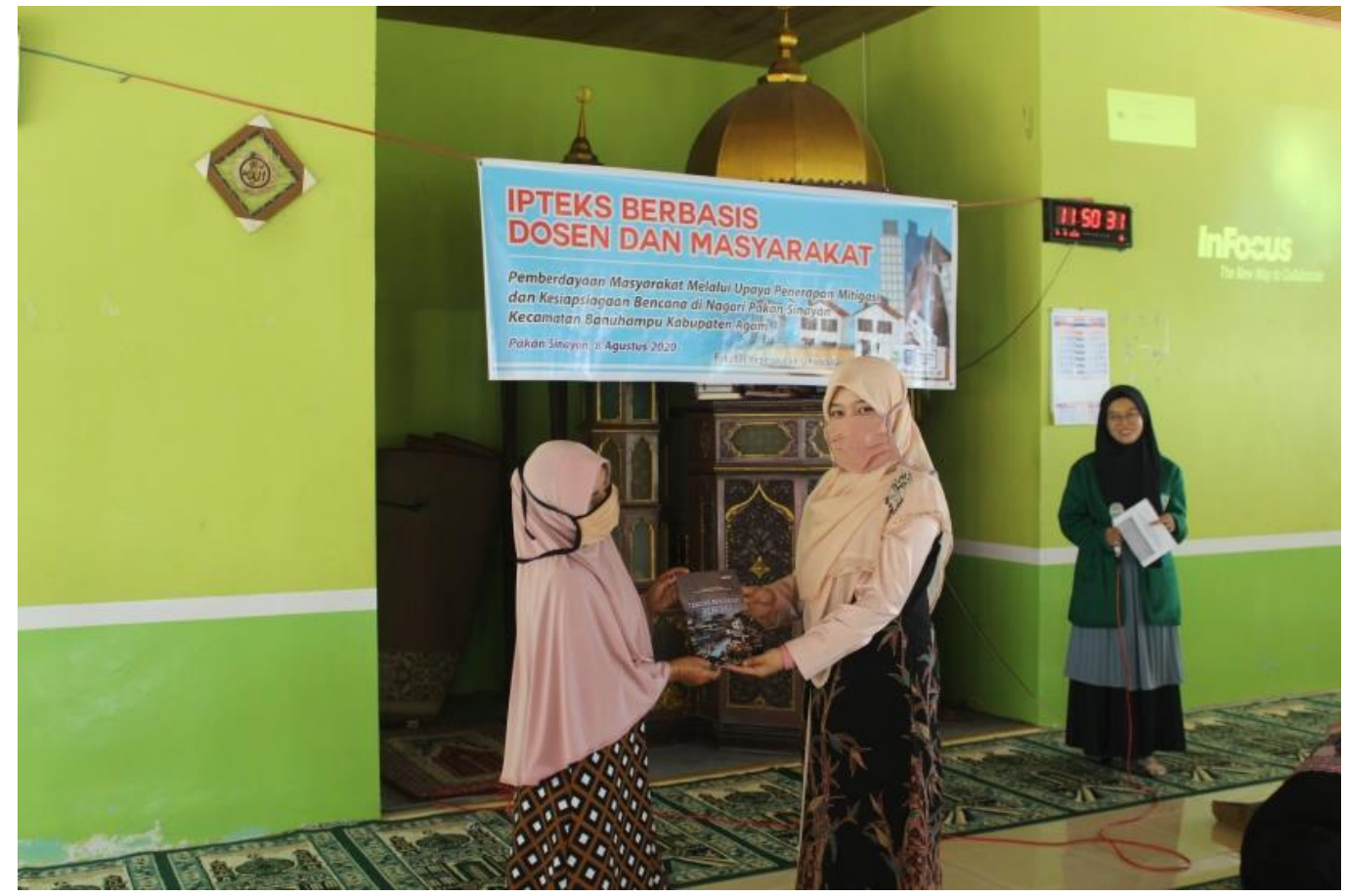

Gambar 3. Penyerahan buku tangguh mengadapi bencana

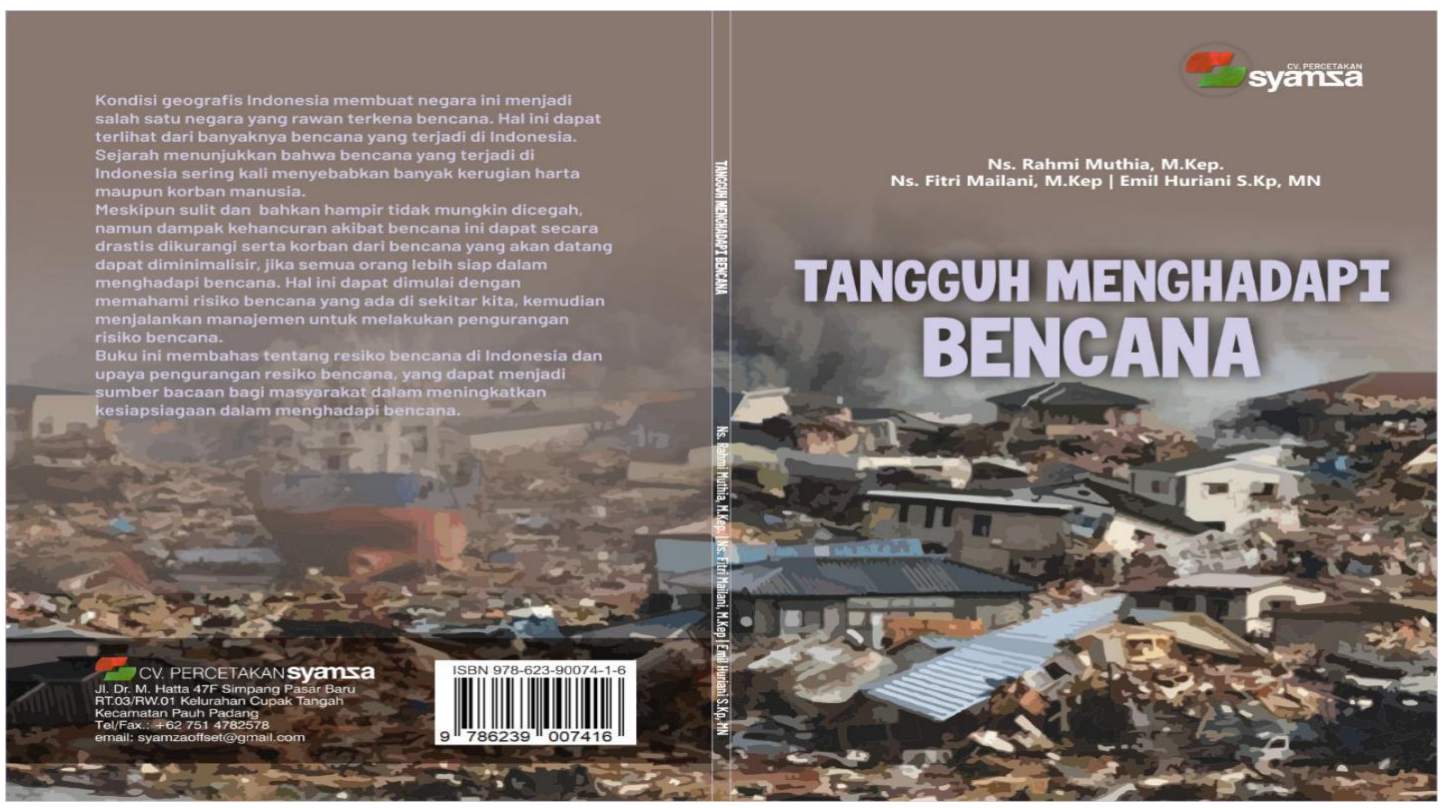

Gambar 4. Cover buku yang dibagikan kepada masyarakat yang mengikuti pelatihan

\section{KESIMPULAN DAN SARAN}

Penanganan bencana harus dilakukan dengan melibatkan masyarakat itu sendiri. Kesadaran penanggulangan bencana pada masyarakat akan hadir bila masyarakat memiliki pemahaman yang benar tentang bencana. Pelatihan kebencanaan akan berpengaruh terhadap pengetahuan dan cara masyarakat menyikapi bencana. Hendaknya kegiatan ini dilakukan berkesinambungan, supaya terjadi lebih terjaminnya kenaikan pada kesiapsiagaan bencana pada masyarakat. 


\section{DAFTAR PUSTAKA}

Afrianti, E., Nofrizon, Rika. F, dkk (2019). Pemberdayaan Masyarakat Muda Sekolah Melalui Upaya Penerapan Mitigasi dan Tanggap Darurat Bencana. Jurnal Warta Andalas. Vol 26 No 4.b.

BNPB. (2008). Pedoman penyusunan rencana penaggulangan bencana. Jakarta: BNPB.

BNPB. (2008). Peraturan Kepala BNPD No 11 Tahun 2008 Tentang Pedoman Rehabilitasi dan Rekonstruksi Pasca Bencana. Jakarta.

BNPB. (2015) ,Pengetahuan Bencana.,Sistem Penanggulangan Bencana. http://www.bnpb.go.id.

Damayanti, D. P. W. R. M. (2017). Hubungan Pengetahuan tentang Manajemen Bencana dengan Prevention Masyarakat dalam Menghadapi Bencana Gunung Meletus pada Kepala Keluarga di RT 06/RW 01 Dusun Puncu Kecamatan Puncu Kediri. Jurnal Ilmu Kesehatan, 5(2), 115127.

Daud, R., Sari, S. A., Milfayetty, S., \& Dirhamsyah, M. (2014). Penerapan Pelatihan Siaga Bencana dalam Meningkatkan Pengetahuan, Sikap, dan Tindakan Komunitas SMA Negeri 5 Banda Aceh. Jurnal Ilmu Kebencanaan (JIKA), 1(1), 26-34.

Herianto, R., Nulhaqim, S. A., \& Rachim, H. A. (2015). Community Based Disaster Management (pp. 326-330).

Kurniawati, D. S. (2016). Pengaruh Pengetahuan Kebencanaan Terhadap Sikap Kesiapsiagaan dalam Menghadapi Bencana pada Mahasiswa Program Studi Pendidikan Geografi Universitas Kanjuruhan Malang. eJournal.unikama, 135-142. Retrieved from ejornal.unikama.ac.id/index/php/JPIG/issue/download/260/25

Mahathir, Fitra Y., Agus S.B., (2019).Pendidikan Kesiapsiagaan Bencana Pada Anggota Keluarga dalam Mewujudkan Keluarga Tangguh Bencana. Jurnal Warta Andalas. Vol 26 No 4.c.

Notoatmodjo, S. 2003. Pendidikan dan perilaku Kesehatan. Jakarta: Rineka Cipta.

Nurudin, A. (2015). Pengaruh Pelatihan Penanggulangan Bencana Gempa Bumi Terhadap Kesiapsiagaan Siswa Kelas Vii Di Smp Negeri 1 Imogiri Bantul Yogyakarta.

Ramli, S. (2010). Pedoman Praktis Manajemen Bencana (Disaster Manajemen). Jakarta: Dian Rakyat.

Susanto, N Dan Thomas T.P., (2016). Analisis Level Kesiapan Warga Menghadapi Potensi Bencana Longsor Kota Semarang. Teknik, 37(2), 2016, 58.

Whitehead D. 2004, 'Health promotion and health education: advancing the concepts', Journal of Advanced Nursing, vol. 47, no. 3, pp. 311-20. 